\title{
The Impact of Leader -Member Exchange Relationship on Employee Performance Appraisal Reaction: The Mediating Role of Organizational Justice
}

\author{
Lanyun Wang ${ }^{\mathrm{a}}$, Xiangdong Wang ${ }^{\mathrm{b}}$ and Dan Song ${ }^{\mathrm{c}, *}$ \\ School of Business, Tianjin University of Finance and Economics, Tianjin 300222, China \\ awlyn2007@163.com, b372682716@qq.com, c1139915329@qq.com \\ *Corresponding author
}

Keywords: Leader -member exchange relationship, Performance appraisal reaction, Organizational justice

\begin{abstract}
In recent years, the social context of performance appraisal has received extensive attention, especially it is considered to have an important impact on employee performance appraisal reaction. Based on the investigation of Beijing, Tianjin and Hebei Provinces, this paper examines the impact of leader -member exchange relationship on employees' performance appraisal reaction, and tests the mediating role of organizational justice. The study found that the leader -member exchange relationship have a positive impact on employee performance appraisal satisfaction, and employee perception of organizational justice plays an mediation role in the exchange of leadership- members and employee performance appraisal satisfaction.
\end{abstract}

\section{Introduction}

Performance appraisal is one of the most commonly used management tools in organizations and one of the most frequently studied topics in management area (Arvey \& Murphy, 1998). For a long time, the study for performance appraisal focuses on the accuracy of evaluation and take it as performance appraisal standards. Nowadays, more and more scholars focus on qualitative performance appraisal instead of quantitative performance appraisal as evaluation criteria, because scholars realize that even a well-designed performance appraisal system may be damaged by employees' negative performance appraisal reaction (Murphy \& Cleveland, 1995).

Employee performance appraisal reaction is a very important part of performance appraisal standard (Balzer \& Sulsky, 1990). For any organization, employee performance appraisal reaction is crucial to the effectiveness of performance appraisal system (DeNisi \& Gonzalez, 2000). And the employee's work attitude and future job performance are closely related to the employee's performance appraisal reaction (Nathan, Mohrman, \& Milliman, 1991).

More important, the performance appraisal process takes place in a social context (Murphy \& Cleveland, 1995) and the relationship between supervisor and employee is a key variable affecting employee performance appraisal reaction (Elicker, Levy, \& Hall, 2006). Therefore, appraisal reaction should be studied in a social context (Levy \& Williams, 2004), and as a result, more and more scholars have begun to put attention to social context factors of performance measurement in recent years (Levy \& Wulliams, 2004). Some scholars generally agree that the social context of performance appraisal has an important influence on employees' performance appraisal reaction, but there is no accurate and clear understanding for the specific links between them. Shaun (2012)' analysis shows that the exchange relationship of leader- member has an important impact on employee performance evaluation reaction, and the fairness of the procedure and employee participation in the performance evaluation process has an important influence. Based on the above discussion, this paper examines the impact of leader -member exchange relationship on employees' performance appraisal reaction, and tests the mediating role of organizational justice. 


\section{Model Construction and Theoretical Assumptions}

\subsection{The Leader -Member Exchange Relationship and employee Performance Appraisal Reaction}

The leader - member exchange relationship theory thinks that the leaders do not treat their employees equally (Dansereau, Graen, \& Haga, 1975, Graen \& Cashman, 1975). That is, Subordinates have different levels of relationships with leader. The quality of the relationship often depends on a number of different factors such as personal charisma and employee performance (Gerstner \& Day 1997; Graen \& Uhl-Bien 1995; Varma \& Stroh 2001). In general, higher-quality relationships tend to bring more mutual trust, mutual support and sharing and exchange of resources. Lower-quality relationships means no more these kind advantages (Liden, Sparrowe, \& Wayne, 1997; Maslyn \& Uhl-Bien, 2001).

In performance appraisal process, employees who have higher quality relations with their superiors tend to receive some special treatment (Scandura, Graen, \& Novak, 1986), and these employees are also allowed to participate in the appraisal process during the performance appraisal (Wexley \& Klimski, 1984), and eventually these employees tend to get satisfactory results (Wayne, Shore, Bommer, \& Tetrick, 2002). Some study shows that if employees have a voice in any organizational process, they tend to think they can have an influence on the process, and tend to be more satisfied with the process (Folger, 1977; Lind \& Tyler, 1988).

Based on the above discussion, we assume that:

H1: The exchange of leadership members has a positive impact on the employee's performance appraisal satisfaction.

\subsection{The Mediation Role of Organizational Fair}

Organizational justice refers to employees' perception of equity in organization (Greenberg, 1990). Procedural fairness is one of dimensions for organizational justice, it refers to the fairness of procedures associated with the allocation of outcomes. Researches shows that employees are not only concerned with what they have achieved, they are equally concerned with the process of getting those results (Nowakowski \& Conlon, 2005; Thibaut \& Walker, 1975). Another dimensions of organizational justice is interactive fairness, it refers to the influence of the executors 'attitudes and methods on the employees' fair perception(Bies \& Moag, 1986). Greenberg $(1990,1993)$ again divides the interaction into two parts: fairness and fairness.

Some study have pointed out that if leaders allow employees to participate in the decision making process Even if employees have no material impact on the outcome of the decision-making process, the perception of fairness will be greatly enhanced (Lind et al., 1990). Scholars' research also shows that if employees can participate in the performance appraisal process, employees often have a positive and beneficial reaction to the performance appraisal process (Cawley et al., 1998). And procedural fairness theory also points out that the quality of the relationship between employees and their superiors is an important prerequisite variable in their performance appraisal responses (Lind, Kanfer, \& Earley, 1990). Also, some study find that the exchange relationship of leader -members can influent employee's reaction on appraisal actively. (Elicker et al., 2006). Based on the above discussion, we propose a typothesis as:

H2: The leader- member exchange relationship will have a positive impact on perceived processes fairness of employees.

H3: Employee perceived procedural fairness can have a positive impact on its performance appraisal satisfaction.

The leader- members exchange relationship theory assume that the exchange of resources and information between leaders and employees is an important guarantee for maintaining a good relationship for them(Wayne et al., 2002). Humans are social animals and that interpersonal relationships is very important for human being (House, Landis, \& Umberson, 1988). And leader members exchange relationship theory suggests that better quality of superior and subordinate relationships tend to give employees more preferential treatment in the performance appraisal 
process (Scandura, Graen, \& Novak, 1986). At same time, leaders tend to give employees more trust and more information (Cleveland \& Murphy, 1992).Meanwhile , they may give them more opportunities to influence their superiors and participate in the performance appraisal process (Wexley \& Klimoski , 1984). In return for superior preferential treatment in the performance appraisal process, employees tend to have a positive response in the performance appraisal process, which often has a positive impact on the future performance, so the employee's performance appraisal response can be considered as an integral part of leader -member exchange relationship. Based on the above discussion, we assume:

H4: The leader -member exchange relationship may have a positive impact on employee-perceived interactive fairness.

H5: Employee's perception of interactive fairness may have a positive impact on their performance appraisal satisfaction.

H6: Employee's perception of procedures fairness play an mediation role on leader- member exchange relationship and employee appraisal satisfaction.

H7: Interactive fairness perception of employee plays an mediation role on leader- member exchange relationship and employee appraisal satisfaction.

Based on above discussion, we propose the following hypothesis model as following:

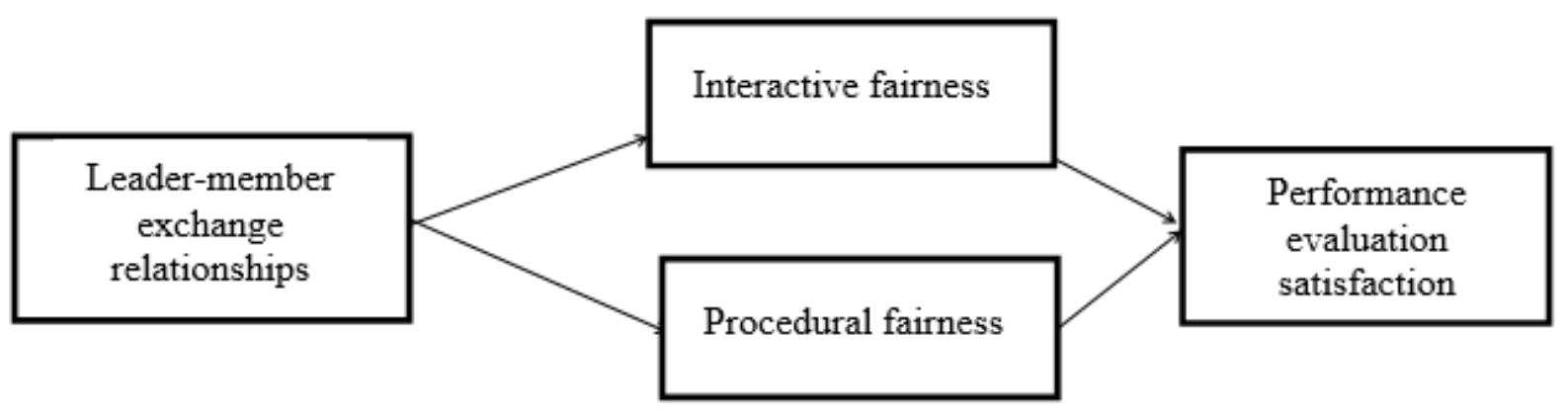

Fig.1 hypothesis model

\subsection{Variable Measurement}

The questionnaire consists of three sections, which are used to measure the leader- member exchange relationship, organizational fairness and employee evaluation resaction. All questions using Likert five-point system, letting participants to fill in, from 1 to 5 were "totally disagree", "disagree", "uncertain", "agreed" and "fully agree". The Leading Member Exchange Scale draws on the LMX questionnaire prepared by Graen and Uhl-Bien for a total of seven questions. The Evaluation Satisfaction Scale draws on the scale developed by Meyer and Smith (2000), which contains a total of seven questions and Kuvaas (2006) made a slight adjustment to the scale in his study, culminating in 6 A question on employee satisfaction evaluation to measure. The Organizational Fairness Scale draws on the three-factor scale of organizational justice developed by Luo Jing (2007).

\subsection{Data Collection}

We conducted a survey of employees in Beijing, Tianjin and Hebei Provinces using questionnaires. The distribution channels mainly include questionnaire star, WeChat group, etc., and obtain the required data. In this survey, 300 questionnaires were issued and 270 questionnaires were withdrawn. A total of 267 valid questionnaires were obtained after screening unqualified questionnaires, with an effective recovery rate of $89 \%$.

\subsection{Analysis Methods}

For data analysis, the article used SPSS.21 to process data. The data analysis process is as follows: (1) Cronbach's $\alpha$ is used to evaluate the reliability of the data, and the validity of the 
questionnaire is verified by the method of confirmatory factor; (2) After the reliability and validity of the test, the correlation between the various variables is tested, followed by linear regression test.

The reliability coefficient values of all scales in the questionnaire are higher than 0.7 , and the overall internal consistency coefficient of the questionnaire is 0.872 . Therefore, the reliability of the questionnaire used in this study is relatively high. The overall KMO of the questionnaire is 0.802 , and the KMO of all variables are above 0.7 . Generally speaking, the KMO is not suitable for factor analysis when it is lower than 0.6 , so the reliability of the questionnaire is good.

\subsection{Related analysis}

At this stage we analyze the correlation between variables, and we can get the correlation between variables by Pearson's correlation coefficient. Table 3 shows that there is a significant correlation between leader-member exchange relationships, fairness of procedures, fairness of interaction and employees' satisfaction with performance appraisal. The correlation coefficient is shown in Table 1

Table 1 Related Analysis Table

\begin{tabular}{|c|c|c|c|c|}
\hline variables & 1 & 2 & 3 & 4 \\
\hline $\begin{array}{l}\text { 1.Leading members exchange } \\
\text { relationships }\end{array}$ & 1 & & & \\
\hline 2.Procedural fairness & $.310^{\cdots \cdots}$ & 1 & & \\
\hline 3.Interactive fairness & .339 & .236 & 1 & \\
\hline 4.Assessment satisfaction & .344 & $.368^{\cdots \cdots}$ & $.297^{\cdots \cdots}$ & 1 \\
\hline
\end{tabular}

Note: ** indicates significant correlation at 0.01 level (bilateral), *. Indicates significant correlation at 0.05 level (bilateral).

\section{Regression Analysis and Hypothesis Testing}

\subsection{The leader- member exchange relationship and performance appraisal satisfaction}

Table 2 Leadership members exchange relationship and assessment satisfaction regression analysis results

\begin{tabular}{l|c|c|c|c|c|c}
\hline \multicolumn{2}{c|}{ model } & $\begin{array}{c}\text { Non-standardized } \\
\text { coefficient }\end{array}$ & $\begin{array}{c}\text { Standard } \\
\text { coefficient }\end{array}$ & \multirow{2}{*}{$\mathrm{t}$} & \multirow{2}{*}{ Sig } \\
\cline { 3 - 5 } \multicolumn{2}{c|}{} & B & $\begin{array}{c}\text { Standard } \\
\text { error }\end{array}$ & trial version & & \\
\hline \multirow{2}{*}{1} & (constant) & 2.541 & .247 & & 10.287 & .000 \\
\cline { 2 - 5 } & $\begin{array}{c}\text { Exchange } \\
\text { relationship }\end{array}$ & .339 & .066 & .344 & 5.908 & .000 \\
\hline
\end{tabular}

Dependent variables: Employee assessment satisfaction

Table 2 shows the results of the regression analysis between the relationship between leaders and employee performance appraisal satisfaction. As can be seen from the tabular data, the correlation coefficient between the exchange of leadership members and employee satisfaction is 0.344 , and $\mathrm{p}$ $=0<0.05$, which indicates that there is a significant positive impact on employee satisfaction The exchange relationship of leader- member plays an active role in employee satisfaction assessment, hypothesis $\mathrm{H} 1$ is confirmed.

\subsection{The relationship between organizational justice and performance appraisal satisfaction}

Table 3 shows the results of regression analysis between organizational justice and employee performance appraisal satisfaction. As can be seen from the tabular data, the correlation coefficient between procedural fairness and employee performance appraisal satisfaction is 0.368 , and $\mathrm{p}=0<0.05$, which indicates that procedural fairness has a significant positive impact on employee performance appraisal satisfaction degree is 0.297 , which shows that interactive fairness has a significant positive impact on performance appraisal satisfaction degree, that is, interaction and fairness are satisfied with employee's examination Degree play a positive role, assuming H3, H5 is verified. 
Table 3 Organizational Justice and performance appraisal Satisfaction Regression Analysis Results

\begin{tabular}{c|c|c|c|c|c|c}
\hline \multicolumn{2}{c}{ model } & \multicolumn{2}{c|}{$\begin{array}{c}\text { Non-standardized } \\
\text { coefficient }\end{array}$} & $\begin{array}{c}\text { Standard } \\
\text { coefficient }\end{array}$ & \multirow{2}{*}{$\mathrm{t}$} & Sig \\
\cline { 3 - 5 } \multicolumn{2}{c|}{} & $\mathrm{B}$ & $\begin{array}{c}\text { Standard } \\
\text { error }\end{array}$ & trial version & & \\
\hline \multirow{2}{*}{1} & (constant) & 2.280 & .276 & & 8.273 & .000 \\
\cline { 2 - 6 } & $\begin{array}{c}\text { Procedural } \\
\text { fairness }\end{array}$ & .423 & .077 & .368 & 5.506 & .000 \\
\hline \multirow{2}{*}{2} & (constant) & 2.531 & .291 & & 8.704 & .000 \\
\cline { 2 - 5 } & $\begin{array}{c}\text { Interactive } \\
\text { fairness }\end{array}$ & .372 & .086 & .297 & 4.331 & .000 \\
\hline
\end{tabular}

Dependent variables: Employee assessment satisfaction

\subsection{The relationship between leader-member exchange relationship and organizational justice}

Table 4 organizational justice and performance appraisal satisfaction regression analysis results

\begin{tabular}{|c|c|c|c|c|c|c|}
\hline & \multirow{2}{*}{ model } & \multicolumn{2}{|c|}{$\begin{array}{c}\text { Non-standardized } \\
\text { coefficient }\end{array}$} & \multirow{2}{*}{$\begin{array}{c}\text { Standard } \\
\text { coefficient }\end{array}$} & \multirow{2}{*}{$\mathrm{t}$} & \multirow{2}{*}{ Sig } \\
\hline & & B & Standard & & & \\
\hline \multirow[b]{2}{*}{1} & (constant) & 2.549 & .218 & & 11.720 & .000 \\
\hline & $\begin{array}{l}\text { Exchange } \\
\text { relationship }\end{array}$ & .266 & .058 & .310 & 4.542 & .000 \\
\hline \multirow[b]{2}{*}{2} & (constant) & 2.351 & .198 & & 11.901 & .000 \\
\hline & $\begin{array}{l}\text { Exchange } \\
\text { relationship }\end{array}$ & .266 & .053 & .339 & 5.011 & .000 \\
\hline
\end{tabular}

Dependent variables: organizational justice

Table 4 shows the results of the regression analysis between the exchange of leader- members exchange relationship and the organizational justice perceived by employees. In the model 1, due to the fact that the program is fair, the model 2 is interactive and fair because of the variables. As can be seen from the tabular data, the correlation coefficient between leader-member exchange relationship and employee-perceived process fairness is 0.310 , and $\mathrm{p}=0<0.05$, indicating a significant positive impact on the fairness of procedures perceived by employee and leadermember exchange relationship. In other words, from the model 2 data, the relationship coefficient between leader- member exchange and employee perception is 0.339 , and $p=0<0.05$, which shows that leader- member exchange relationship has a significant positive impact on the interactive equity perceived by employees. That is, leader- member exchange relationship plays an active role in the interactive fairness of employee perceptions, and $\mathrm{H} 2$ and $\mathrm{H} 4$ are assumed to be validated.

\subsection{Organizational justice mediation analysis}

Table 5 Employee-aware Procedures Fair Mediation Effect Analysis Results

\begin{tabular}{|c|c|c|c|c|c|c|}
\hline & \multirow{2}{*}{ model } & \multicolumn{2}{|c|}{$\begin{array}{c}\text { Non-standardized } \\
\text { coefficient }\end{array}$} & \multirow{2}{*}{$\begin{array}{c}\text { Standard } \\
\text { coefficient } \\
\text { trial version }\end{array}$} & \multirow{2}{*}{$\mathrm{t}$} & \multirow{2}{*}{ Sig } \\
\hline & & B & $\begin{array}{c}\text { Standard } \\
\text { error }\end{array}$ & & & \\
\hline \multirow[b]{2}{*}{1} & (constant) & 2.541 & .247 & & 10.287 & .000 \\
\hline & $\begin{array}{l}\text { Exchange } \\
\text { relationship }\end{array}$ & .339 & .066 & .344 & 5.098 & .000 \\
\hline \multirow{3}{*}{2} & (constant) & 1.694 & .309 & & 5.475 & .000 \\
\hline & $\begin{array}{l}\text { Exchange } \\
\text { relationship }\end{array}$ & .250 & .067 & .254 & 3.738 & .000 \\
\hline & Satisfaction & .332 & .078 & .289 & 4.248 & .000 \\
\hline
\end{tabular}

a. dependent variable: satisfaction

From Table5, we can see that the staff satisfaction coefficient of performance appraisal decreased from 0.344 to $0.254, p=0<0.05$, employee satisfaction coefficient $0.289, p=0<0.05$, Therefore, the employee-perceived program fairness plays an mediation role between leader- member exchange relationship and employees' performance evaluation satisfaction, it means that H6 has 
been verified.

Table 6 organizational justice Mediation Effect Analysis Results

\begin{tabular}{c|c|c|c|c|c|c}
\hline \multirow{2}{*}{ model } & \multicolumn{2}{c|}{$\begin{array}{c}\text { Non-standardized } \\
\text { coefficient }\end{array}$} & $\begin{array}{c}\text { Standard } \\
\text { coefficient }\end{array}$ & \multirow{2}{*}{ Sig } \\
\cline { 3 - 5 } \multicolumn{2}{c|}{} & $\mathrm{B}$ & $\begin{array}{c}\text { Standard } \\
\text { error }\end{array}$ & \multirow{2}{*}{ trial version } & & \\
\hline \multirow{2}{*}{1} & (constant) & 2.541 & .247 & & 10.287 & .000 \\
\cline { 2 - 5 } & $\begin{array}{c}\text { Exchange } \\
\text { relationship }\end{array}$ & .339 & .066 & .344 & 5.098 & .000 \\
\hline \multirow{3}{*}{2} & (constant) & 1.940 & .319 & & 6.085 & .000 \\
\cline { 2 - 5 } & $\begin{array}{c}\text { Exchange } \\
\text { relationship }\end{array}$ & .271 & .069 & .275 & 3.906 & .000 \\
\cline { 2 - 5 } & Satisfaction & .255 & .088 & .204 & 2.900 & .004 \\
\hline
\end{tabular}

a. dependent variable: satisfaction

From Table 6, we can see that the employee evaluation satisfaction coefficient has been reduced from 0.344 to 0.275 after adding the mediators of mediation variables, $p=0<0.05$, employee satisfaction coefficient $0.204, \mathrm{p}=0<0.05$, Therefore, employee-perceived interactive fairness plays an mediation role in leader- member exchange relationship and employee performance appraisal satisfaction, hypothesis $\mathrm{H7}$ is validated.

\section{Conclusion and Discussion}

\subsection{Research Conclusion}

The purpose of this paper is to explore the influence of leader- member exchange relationship on employee performance appraisal reaction, and to join in the variable of organizational justice to deeply explore the mediation effect. Based on the relevant research, combining with related theories, using questionnaire survey method and data analysis process, the following conclusions is obtained:

First, the leader-member exchange relationship has a positive impact on employee performance appraisal satisfaction. When leader and employee in performance appraisal process having established a good working relationship, employee appraisal satisfaction will be greatly enhanced; Second, for organizational justice, this paper mainly studies the two aspects of fairness: procedural fairness and interactive fairness. Analysis show that, employee perceived procedural fairness and interactive fairness all have a positive impact on employee appraisal satisfaction. Third, leader-members exchange relationship can have a positive impact on the organizational justice perceived by employees. Meanwhile, the organizational fair perceived by employees plays an mediation role between leader- member exchange relationship and employee appraisal satisfaction.

\subsection{Discussion and the Meaning of Management}

In recent years, employees reaction to performance appraisal has drawn more and more attention because employees' reaction is one of the most important criteria to judge whether performance evaluation system is effective (Levy and Williams 2004; Pichler 2012). This study explores the impact leader- member exchange relationship on employee performance appraisal satisfaction by empirical research. First, that is, leader- member exchange relationship can have a positive impact on employee performance appraisal satisfaction. When leaders trust employees, they will delegate a certain degree of authority and employees has a right of speech. Employees consider themselves being valued and they will be tend to give a positive reaction in performance appraisal process. Through continuous accumulation of feelings between leader and member, the establishment of a high-quality exchange relationship in performance appraisal will improve employee appraisal satisfaction. Second, Organizational justice has a mediation effect on the relationship between leader- member exchange and employee performance appraisal satisfaction. A good working relationship between leaders and employees has a positive impact on organizational fairness perceived by employees. When there are an good leader- member exchange relationship, employee will perceived more organizational fairness, and this help employee to feel more performance 
appraisal satisfaction. When leader's decision-making process is open or involving employees in person, it may greatly increase the sense of fairness of employee. When employees feel fair in these areas, they will be more loyal and dedicated, work hard to repay the organization, and have a positive response to the performance appraisal process.

This study bring us some important management enlightenments: In order to promote positive reaction of employees, leaders should try their best to maintain a good working relationship with employees, and in the process of formulating organizational performance decisions, adopting a fair and equitable approach to enhance employee's organizational justice sense. So, to improve performance management system effectiveness, managers must put attention to employee's acceptance to it. This means that the process of performance system is founded, the process of performance plan' communication with employees, and the process of performance coaching, are all related to the success of performance appraisal.

The main limitations of this study are: First, all the research data comes from the personal self-report of employees, which increases the possibility of error. In the future work, we should consider collecting data from multiple sources to further improve the data validity; Second, it is only choosing employee performance satisfaction to represent employee reaction, in future work, other employee reaction in performance appraisal should also give the appropriate attention.

\section{Acknowledgements}

This research was supported by Tianjin Philosophy and Social Sciences Planning Key Project "Impact of Performance Appraisal Perception on Innovative Behavior of Knowledge Workers" (No. TJGL16-007).

\section{References}

[1] Lin Ding, You-Min XI, Hua Zhang, Transformational Leadership and Staff Innovation: The Mediating Role of Leadership - Affiliation [J]. research management, 2010.31 (1): 177-184.(In Chinese)

[2] Rui Sun, Jin-tao Shi, Ti-qin Zhang, An Empirical Study on the Relationship between Leader-member Exchange, Team-member Exchange, Organizational Climate and Employee Innovation Behavior in Chinese Enterprises[J]. Chinese Journal of Management Engineering 2009,23 (4). (In Chinese)

[3] Qian LI, Rui Sun, Study on Social Exchanges, Knowledge Sharing and Innovative Behavior of Employees in Enterprises[J]. Science of Science and Management of Science and Technology, 2015,36 (10). (In Chinese)

[4] Peng Wen, Jian-Qiao Liao, Different types of performance appraisal staff differences in the response to the assessment [J]. Nan kai Management Review, 2010,13 (2): 142-150. (In Chinese)

[5] Xue-Fei He. The relationship between performance appraisal satisfaction and employees' work behaviors: the mediation effect of intermediaries[D]. Tianjin Normal University, 2016. (In Chinese)

[6] Xin-yan Wang, Jian-Qiao Liao. Research on the Impact Mechanism of Organizational Justice on Employee Job Performance [J]. Jiang xi Social Sciences, 2007. (In Chinese)

[7] Can-wu Li. Research on the Relationship between Organizational Justice and Employee Work Attitude[J]. Jiang Su Business Theory, 2010 (30): 146-146. (In Chinese)

[8] Xian-Feng Gao. Research on the Relationship between Leadership - Membership Exchange and Organizational Citizenship Behavior [D]. An Hui University, 2011. (In Chinese)

[9] Jin-Hong Xue. Empirical Study on the Relationship between Leadership - Member Exchange and Organizational Citizenship Behavior and Mission Performance[D]. Shanghai Jiao Tong University, 2011.(In Chinese) 
[10] Atwater L, Carmeli A. Leader-member exchange, feelings of energy, and involvement in creative work [J]. The Leadership Quarterly, 2009, 20 (3): 264-275

[11] Bard Kuvaas. The interactive role of performance appraisal reactions and regular feedback [J]. Journal of Managerial Psychology, 2011, 26 (2): 123-137

[12] Bard Kuvaas. Performance appraisal satisfaction and employee outcomes: mediating and moderating roles of work motivation [J]. The International Journal of Human Resource Management, 2006,17 (3): 504-522

[13] The mediating role of goal interdependence and the moderator role of procedural justice [J]. Personnel Review, 201 l, 40 (1): 87-105

[14] Brian D. Cawley, Lisa M. Keeping and Paul E. Levy. Participation in the Performance Appraisal Process and Employee Reactions: A Meta-Analytic Reviews of Field Investigations [J]. Journal of Applied Psychology, 1998, 83): 615-633

[15] Pichler S. The social context of performance appraisal and appraisal reactions: A meta-analysis [J]. Human Resource Management, 2012, 51 (5): 709-732.

[16] Jing Luo. Knowledge workers performance evaluation fairness and its impact on work attitude [D]. Huazhong University of Science and Technology, 2007. (In Chinese)

[17] Elicker JD, Levy PE, Hall R J. The Role of Leader-Member Exchange in the Performance Appraisal Process [J]. Journal of Management Official Journal of the Southern Management Association, 2006, 32 (4): 531-551. 